\title{
Epidemiology and Knowledge of First Aid Treatment Related to Burn Injury in the Rural Region of Kulon Progo, Indonesia
}

\author{
Rianto Noviady Ramli ${ }^{1}$, Almas Nur Prawoto ${ }^{2 *}$, Nyoman Putu Riasa ${ }^{3}$, Iswinarno Doso Saputro ${ }^{4}$, Ahmad Fawzy Mas'ud ${ }^{5}$ \\ ${ }^{1}$ Division of Plastic, Aesthetic and Reconstructive Surgery, Department of Surgery, Faculty of Medicine, Public Health \\ and Nursing, Gadjah Mada University, Dr. Sardjito Hospital, Yogyakarta, Indonesia; ${ }^{2}$ Wates Public Hospital, Kulon Progo, \\ Yogyakarta, Indonesia; ${ }^{3}$ Division of Plastic, Reconstructive and Aesthetic Surgery, Department of Surgery, Faculty of Medicine, \\ Udayana University, Sanglah General Hospital, Denpasar, Bali, Indonesia; ${ }^{4}$ Department of Plastic, Reconstructive and \\ Aesthetic Surgery, Airlangga University, Dr. Soetomo Hospital, Surabaya, Indonesia; ${ }^{5}$ Department of Plastic, Aesthetic and \\ Reconstructive Surgery, General Soedirman University, Purwokerto, Indonesia
}

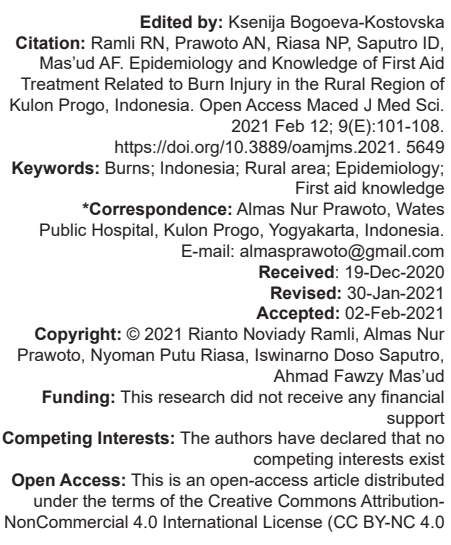

NonCommercial 4.0 International License (CC BY-NC 4.0

\section{Abstract}

BACKGROUND: We investigated the epidemiology and the knowledge of first aid regarding to burns in the rural area of Kulon Progo, located in Indonesia. Although 44\% of Indonesia's population resides in rural areas, data of burn in Indonesia are very limited to national referral centers located in Indonesia's largest cities. We also surveyed the patients and families of these burn patients to try to understand their knowledge on the first aid of burns.

AIM: We wanted to explore and discover what myths and misperceptions existed in rural communities.

MATERIALS AND METHODS: A retrospective study analyzing the medical records of patients with burns admitted to two of Kulon Progo's largest referral hospitals between January 2018 and December 2019. A survey was distributed to the patients and their families regarding their knowledge on the first aid of burns. We wanted to analyze if certain groups of the population were more at risk for specific types of burn etiologies, the correlation between burn etiology and length of stay, the correlation between total body surface area (TBSA) of burns and length of stay in the hospital, and the correlation between education level of survey participants' and their knowledge of first aid of burns.

RESULTS: A total of 115 patients were reviewed in this study. The highest proportion of total burn injuries occurred in the age group of 1-14 years old (38\%). The major etiology of all burn cases were caused by scald $(54 \%)$. Housewives and children were at a higher risk for scalds and laborers were at a higher risk for electrical and chemical burns $(p=0.001)$. There was no significant correlation between etiology and length of stay $(p=0.29)$. There was a statistically significant correlation between the TBSA and the length of hospital stay $(p=0.0001)$. The majority of survey respondents $(66 \%)$ had poor knowledge on the first aid of burns. There was no significant correlation between education level and knowledge of first aid of burns $(p=0.07547)$.

CONCLUSIONS: Children, laborers, and housewives have a significant risk of suffering from a burn injury. A majority of people still have poor knowledge on the first aid of burns. There was no correlation between education levels and knowledge of first aid burns.

\section{Introduction}

Burn injuries are a serious global public health issue effecting nearly 11 million people worldwide with approximately 300,000 deaths annually and contributes to the increase of morbidity, an increase of days in the hospital and disability [1]. It affects people of all ages from infants to the elderly. Fire-related mortality rates are especially high in South-East Asia (11.6 deaths/100.000 population per year). Low- and middle-income countries such as Indonesia are especially affected. Burns are also the leading cause of disability-adjusted life-years lost in those countries. A number of factors in low- and middleincome countries increase the risks for burn injury are associated with poverty and lack of proper infrastructure. These risks include the type of housing, overcrowding, level of completion of housing, lack of supervision of children, safety education, and targeted interventions [2].
There is very limited data on the statistics and epidemiology of burn injuries in Indonesia. The Indonesian National Health Research states that burn injuries have a prevalence of $0.7 \%$ from the total population. Yogyakarta ranks as the $8^{\text {th }}$ province in Indonesia that has the highest prevalence of burn injuries [3]. Kulon Progo is a rural area and is one of the four regencies within Yogyakarta, Indonesia. The vast majority of the population work as farmers. Approximately $18 \%$ of its people live in under the poverty line, which is much higher than the national average of $9.2 \%$. Half of the population (50.9\%) has a primary school level of education or no formal schooling and only $26 \%$ of the population of Kulon Progo finished secondary school [4]. This vast range of education levels provides challenges to health workers when providing health promotion and education.

Wates Regional Public Hospital and Nyi Ageng Serang Regional Public Hospital are also the two regional 
referral hospitals in Kulon Progo. These two hospitals both have an intensive care unit (ICU) and a High Care Unit (HCU) but do not have a burn unit. Wates Regional Public Hospital has a total capacity of 231 beds including 8 beds for the ICU and 9 beds in the HCU. Nyi Ageng Serang Regional Public Hospital has a total capacity of 67 beds which include 2 beds for the ICU and 3 beds in the HCU. Both hospitals have two general surgeons who manage burn patients. There are currently no burn units or plastic surgeons in the area of Kulon Progo [5].

There has not been any published work on the prevalence of burn injury or knowledge of first aid of burns in Kulon Progo. Due to the lack of data on all levels in Indonesia, it is difficult to have a proper understanding of its epidemiological characteristics and associated risk factors.

Many studies have shown the benefits of knowledge on first aid of burns as an important factor in reducing morbidity and mortality of burns. The causes of burns that are often seen in emergency rooms include burns from flames and scalds. Inside the household is where most burns occur [6]. Most Indonesian households cook using liquefied petroleum gas (LPG) for gas stoves and other cooking appliances. Since there is a lack of education in proper usage of LPG's and the lack of regulation in its usage [7], it contributes to an increase of burns in Indonesia. It is of utmost importance for all members of the family to have a strong understanding the first aid of burns.

In many developing countries such as Indonesia, there exist many misperceptions on how burns should be treated [8]. These misperceptions include applying ice, toothpaste, mud, onion, oils, and when to seek help from a medical professional [9]. Other factors that affect the outcomes of burns include the application of cool running water, the duration of application, and whether or not the patient is brought to see a medical professional. In this study, we aim to understand the clinical features, epidemiology, and knowledge of first aid in the rural region of Kulon Progo Yogyakarta in hopes that it can contribute toward the reduction of morbidity of burns in the future.

\section{Materials and Methods}

Data of outpatients and inpatients that were diagnosed with burn injuries were taken from medical records from two of Kulon Progo's two largest hospitals; Wates Regional General Hospital and Nyi Ageng Serang Regional General Hospital. There are currently no burn units or plastic surgeons in the area of Kulon Progo. There were a total of 127 burn patients from January 2018 to December 2019. Inclusion criteria for this study include all patients from all age groups and both genders with acute burns that resulted in both inpatient and outpatient care. Patients that were referred $(n=7)$ or died $(n=5)$ during care were excluded from the study. After reassessing the exclusion factors, there were a total of 115 that would be discussed in this study.

Multiple factors were examined including patient characteristics (gender, age, and occupation), distance from patient's house to hospital, etiology of burn, burn percentage, length of stay, and clinical outcomes.

We wanted to analyze if certain groups of the population were more at risk for specific types of burn etiologies, the correlation between burn etiology and length of stay, the correlation between total body surface area (TBSA) of burns and length of stay in the hospital, and the correlation between education level of survey participants' and their knowledge of first aid of burns. Descriptive data were expressed as percentages. Correlations between variables were performed using Chi-square, unpaired t-test, and Spearman correlation. $p<0.05$ were considered statistically significant.

This descriptive and cross-sectional study was also conducted to assess the general knowledge and practices on burn first aid among the patients and family of the patients of burn in Kulon Progo. Out of the 115 patients of burn from the year 2018 to 2019, a survey was conducted on knowledge on burn first aid. Using voluntary response sampling, 23 patients and 51 family members responded. The survey was conducted by phone and also by email using a 15-part questionnaire conducted within a period of 2 weeks. These questions included a few basic background questions on the person's demographic and also questions related to knowledge on the first aid of burns. The survey was given in Indonesian and then later translated to English.

Informed consent was obtained from the respondents of the survey, they were also made aware of the advantages their participation of the study could provide to their communities. All data were kept confidential and were only used for statistical analysis. Ethical clearance was obtained from the ethical committee of Wates Public Hospital and Nyi Ageng Serang Public Hospital.

\section{Results}

\section{Age and gender prevalence}

A total of 122 subjects were assessed in this study. The standard international age classification from the United Nations was used to classify the age groups. The highest proportion of both inpatients and outpatients was in patients ages 1-14 $(38 \%, \mathrm{n}=44)$, followed by patients 25-44 years old $(22 \%, \mathrm{n}=25)$, $15-24$ years old $(13 \%, n=15), 45-64$ years old $(12 \%$, $n=14)$, patients $<1$ years old $(11 \%, n=13)$, and above 65 years old $(4 \%, n=4)$ (Figure 1$)$.

The majority of these burn patients were of the male gender $(77 \%, n=89)$. Females accounted for 
$23 \%$ of the burn injuries $(n=26$ ) with a ratio of $3.42: 1$ between males and females (Figure 2).

\section{Occupation profile}

About $46 \%$ of the burn patients in this study were of children younger than 18 years old $(n=53)$. Laborers $(19 \%, \mathrm{n}=22)$ and housewives $(13 \%, \mathrm{n}=15)$ were the two most common occupations in this study. Farmers $(7 \%, n=8)$, white collar workers $(3.5 \%, n=4)$, and students over the age of $18(3.5 \%, n=4)$ were the other occupations that we observed in this study. About $8 \%$ of the subjects in this study had occupations that were unknown $(n=9)$ (Figure 3 ).

\section{Etiology}

The major etiology of all burn cases were caused by scald $(54 \%, n=62)$ and flame injuries in 28 patients $(24 \%)$. About $62 \%$ of all the scald cases in this study were pediatric patients (39 patients). Electrical burns were $10 \%$ of the cases in this study $(n=12)$. Chemical burns accounted for $4 \%$ of the cases $(n=4)$. About $8 \%$ of the patients reported contact burns $(n=9)$. There was a significant correlation between occupation and etiology of burns in this study. Housewives and children under 18 were at a higher risk scalds and laborers were at a higher risk for electrical and chemical burns $(p=0.001)$. There was no significant correlation between etiology and length of stay $(p=0.29)$ (Figure 4).

\section{Depth of burns}

The majority of the patients in this study suffered from a superficial partial-thickness burn (Grade 2B) $(49 \%, n=57$ patients) (Table 1). Superficial partialthickness burns (Grade 2A) accounted for $28 \%$ of all burn injuries in Kulon Progo $(n=32)$. About $14 \%$ of the patients in this study had a third-degree burn $(n=17)$.

\section{TBSA of burns (\%)}

The overall median of TBSA was 9\% (1.0054.00 ). Approximately $32 \%$ of the patients (37 patients) had burns that were higher than $15 \%$ of TBSA. There was a statistically significant correlation between the TBSA and the length of hospital stay ( $p=0.0001)$ (Table 2).

Table 1: Depth of burn injuries

\begin{tabular}{lll}
\hline Depth of burns & $\mathrm{n}$ & Percentage \\
\hline Grade 2A & 32 & 28 \\
Grade 2B & 57 & 49 \\
Grade 3 & 17 & 15 \\
Unknown & 9 & 8 \\
\hline
\end{tabular}

\section{Length of hospital stay and mortality rate}

A majority of the burn patients in this study were outpatients $(61 \% ; n=71)$. The remainder $44 \%$ were inpatients $(n=51)$. These patients had a median length

\section{Table 2: TBSA of burns}

\begin{tabular}{lll}
\hline TBSA $(\%)$ & $\mathrm{n}$ & Percentage \\
\hline $0-5$ & 37 & 32 \\
$6-15$ & 41 & 36 \\
$16-25$ & 16 & 14 \\
$26-35$ & 10 & 9 \\
$36-45$ & 6 & 5 \\
$46-55$ & 5 & 4 \\
\hline
\end{tabular}

TBSA: Total body surface area.

of hospital stay at 6.5 nights (3.00-42.00). Throughout 2018-2019, 5 deaths by severe burns were reported in the Kulon Progo region (Figure 5).

\section{Knowledge on first aid of burn}

A survey was conducted on 24 (32\%) patients of burn and $50(68 \%)$ family members of the patients regarding their knowledge on first aid of burn (total 74 participants). Data regarding the survey participant's gender (Figure 6), education level (Figure 7), and income (Figure 8) are shown in Table 3.

\section{Table 3: Burn first aid knowledge}

\begin{tabular}{lll}
\hline Questions and choices & $\mathrm{n}$ & Percentage \\
\hline Removal of clothing and accessories on burn wound & 70 & 95 \\
Temperature of water to initially treat burn wound & & \\
Warm running tap water $\left( \pm 37^{\circ} \mathrm{C}\right)$ & 11 & 15 \\
Cold running tap water $\left( \pm 15^{\circ} \mathrm{C}\right)$ & 19 & 25 \\
$\quad$ Ice water & 35 & 47 \\
Soap water & 9 & 12 \\
Apply water for & & \\
1-10 min & 52 & 70 \\
$10-15$ min & 18 & 24 \\
20 min & 3 & 4 \\
30 min & 1 & 1 \\
All burn wounds will eventually heal itself & 61 & 82 \\
Application of honey can help with burn wounds & 57 & 77 \\
Application of eggs on the lesion can help with burn wounds & 43 & 58 \\
Application of medicinal oils (cajeput oil, citronella oil, clove oil, & 28 & 38 \\
sandalwood oil, etc.) can help with burn wounds & & \\
Application of toothpaste can help with burn wounds & 46 & 62 \\
Application ice can help with burn wounds & 71 & 96 \\
\hline
\end{tabular}

A large portion of the respondents had a high school education $(66 \%, n=49)$. About 15\% $(n=11)$ of our survey respondents had a tertiary (college) education, $11 \%(n=8)$ had a middle school education, and $8 \%(n=6)$ had a primary level education.

The findings of the knowledge of first aid burns in Kulon Progo showed that out of the 74 participants of the survey, 68\% $(n=50)$ of the patients had family members that experienced burn and $32 \%(n=24)$ experienced burn wounds themselves (Figure 9).

Based on the survey results, we categorized the knowledge the respondents had based the scores. On this 9-question survey, one point was given for each question answered correctly. About $66 \%(n=49)$ of the respondents had poor knowledge, 31\% $(n=23)$ had fair knowledge, and only $3 \%(n=2)$ had good knowledge regarding first aid of burns (Figure 11). In this study, there was no significant correlation between education level and knowledge of first aid $\left(r_{s}=0.20792\right.$, $p$ (2-tailed) $=0.07547$ ). 


\section{Discussion}

Burn injuries contribute to a high number of public health problems, disabilities, and preventable deaths each year. The impact of burn wounds is much deeper in low- and middle-income countries such as Indonesia [1]. Having a better understanding of the patients, risk factors, and the population's knowledge on handling the first aid of burn is an important step in the management of burn wounds [10]. There are many misconceptions on how to initially treat burn within the population that can often times worsen the wound.

In this study, we found a majority of the burn patients to be males with a ratio of $3.42: 1$ between males and females. Men are most likely than women to work in fields that expose them to more risks such as laborers and farmers. Many workers in Indonesia still do not adhere to using the proper personal protective equipment and consequently are exposed to burn wounds. Studies in other Indonesian cities such as Jakarta [11], Surabaya [12], and Bali [13] have also shown to have a higher prevalence in males.

The largest age group that was observed in this study was the pediatric group at $46 \%(n=53)$ of the total patients of burn. This is also seen in many other studies in Indonesia [11] and other countries around the world. The cause of burn injury usually depends on the age of the child. In this study, it was found that most of the patients under the age of 5 -year-old $(12 \%$ of all patients) experienced scald injury with hot water being the most frequent cause. Children are more susceptible to accidental injuries because they often are not aware of the common surrounding dangers around the household such as hot liquids, open fires, and electrical currents [14]. Negligence from the child's caretaker is also a contributing factor in many studies [15]. The second highest group to experience burn injury is patients in the productive and working age group at $18-60$ years old $(40 \%)$. The study on the epidemiology of burns in Surabaya had the working age group as the highest amount of patients that experienced burn injury [12].

A risk factor that is often discussed in burn injuries is occupation. Besides the pediatric group that consisted of the largest portion of the burn patients in this study, laborers and housewives were the two most frequent groups that experienced burn injuries. High-risk occupations included jobs that were at risk for exposure to high voltages of electricity, corrosive materials, and hot objects. A population-based national survey in the US showed that within the working age population, employed men, and women sustained more work-related burn injuries than non-work-related burn injuries [16]. In developing countries, many laborers have to work in rough working conditions, are unregulated and consequently do not adhere to many of the recommended safety guidelines [17]. A study once reported a reduction of $9.5 \%$ in occupational burns due to an improvement in fire prevention and management in the industrial sector [18].

The major etiology of all burn cases were caused by scald in $54 \%(n=62)$ of the patients and flame injuries in $24 \%(n=28)$. About $62 \%$ of all the scald cases in this study were pediatric patients (39 patients). Electrical burns were $10 \%$ of the cases in this study $(n=12)$. Chemical burns accounted for $3 \%$ of the cases $(n=4)$. About $8 \%$ reported contact burns $(n=9)$. There was a significant correlation between occupation and etiology of burns in this study. Housewives and children under 18 were at a higher risk scalds and laborers were at a higher risk for electrical and chemical burns $(p=0.001)$. Studies have shown that nearly a fourth of all burn injuries around the world occur in children under the age of 16 , with a majority of children under the ages of five. Similar to the findings of this study, the most common type of burn injuries are scald [19], [20]. Epidemiological studies on burn patients in Karachi also showed that housewives and laborers were the most likely to attain a burn injury. This is thought to occur because of the absence of safety measures and poor fire control measures [21]. A national survey done in the US revealed that almost half (44\%) of respondents did not believe that burns are a serious danger in their home, despite the fact that $75 \%$ reported that they or a family member had suffered a burn injury at home [22].

Kulon Progo represents many rural areas in Indonesia which are often overlooked. The mortality and morbidity from burns have a strong association with poverty and low literacy rate within the family [23]. In low- and middle-income countries, children seem to have a higher risk of burn compared with children in high-income countries [24]. The unique environment of rural Indonesian households in areas including Kulon Progo is one of the reasons why burn injuries occur. Inside a rural Indonesian household, cooking equipment and arrangements all carry risks. Cooking areas in rural regions such as Kulon Progo are often not enclosed or stand at ground level. Kitchens often carry much risk with the usage of LPG and also open fire stoves. There is a huge lack of education on the precautionary measures of using an LPG. Rural Indonesian households also have a common routine of burning of household garbage every few days in an open flame pit to reduce the volume of waste in their household. This routine poses a large risk for flame injuries to occur in the household.

Unlike the studies conducted in other cities in Indonesia such as Jakarta [11] and Surabaya [12], most patients in this study suffered a second degree burn. This is most likely due to the fact that hospitals in the rural region of Wates are considered secondary healthcare facilities, whereas the studies done in Jakarta and Surabaya were in tertiary healthcare facilities. In Wates, severe burn cases will most likely be referred to a tertiary healthcare facility if there are 
still available beds in the tertiary burn unit. The median of TBSA for the patients in this study was $9 \%(1.00$ $54.00)$ and median for length of hospital stays to be 6.5 nights (3.00-42.00). We also found that there was a statistically significant correlation between TBSA and the length of hospital stay which is often seen in other studies throughout the world [25], [26]. Although these studies often showed women to have longer hospital stays than men, in our research, we found this to be the opposite. This could be because severe burns occurred more in men than in women.

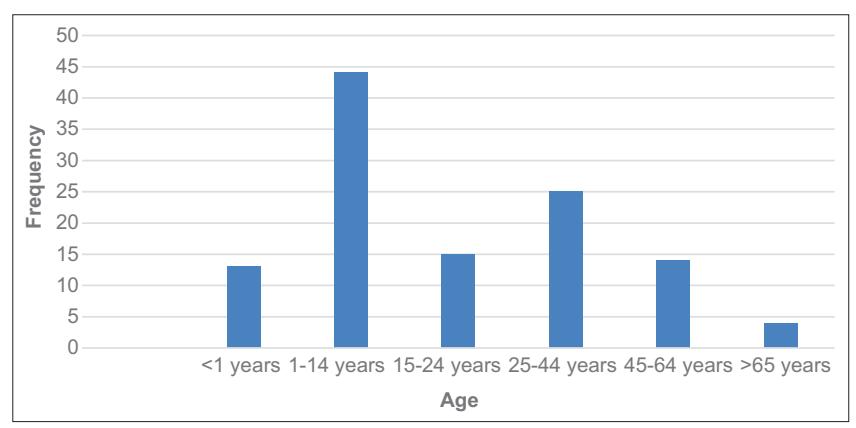

Figure 1: Distribution of burn patients by age

Knowledge of burn first aid is one of the most important factors of the outcome of a burn wound. Application of proper first aid care for burn wounds can help cool the burn faster, reduces pain, edema, histamine release, and stabilize mast cells. All of these factors play a role in improving the end results of burn injuries [27]. It is notoriously known that in developing countries and rural areas across the world, there exist many misconceptions and myths around how to treat burn wounds. Some of these traditional "remedies" can further the damage of the wounds and can present additional problems for health professionals. Uncovering these misperceptions and the practices of the people of Kulon Progo is a critical step in providing proper knowledge on first aid of burn wounds.

According to UNESCO, the national level of literacy for Indonesia is $95.7 \%$ in people $\geq 15$ years and even lower for $\geq 65$ years at $74.3 \%$ [28]. It is standard for the Indonesian education system for its citizens to complete secondary school, although in rural regions such as Kulon Progo, it is not uncommon to have people with a primary school education. A vast majority had children under 18 years old in the household $(88 \%, n=65)$ (Figure 10). Similar with our findings, other studies also show that pediatric patients accounted for the largest group with burn injuries. Having adults with proper knowledge on the first aid of burns can drastically change the course of the burn injury for the better since most burns occur in the house [29].

Majority of respondents (95\%) answered correctly by initially removing clothing and accessories on burn wound. These results are also similar to the study in Arab where $72 \%$ of respondents knew this should be done. Besides removal of the heat sources, clothing can retain heat and continue to prolong the burning process [27]. A study done in Nepal [30] and
Australia [31] showed that only $36.6 \%$ and less than $1 \%$, respectively, of its correspondents would remove clothing and accessories upon burn injury.

Immersion or running cold water on the burn wound for the correct amount of time (20 min) is an important step in cooling of the burn. Running cold water for the correct amount of time can help control pain, reduce swelling by regulating mast cells, thromboxane levels, histamine release, and removing contaminants. Cold water is believed to prevent cells undergoing progressive necrosis 1-2 days after burn in the zone of stasis [30]. Compared to untreated controls, cold water was found to significantly improve the speed of re-epithelialization in $2^{\text {nd }}$ - and $3^{\text {rd }}$-week post-burn. Cold water also results in a thinner wound and a better cosmetic appearance [32], [33]. When asked what temperature should be used to initially treat burns, $47 \%$ of the respondents said ice water was the best option, followed by $25 \%$ with cold running water, $15 \%$ with warm water, and $12 \%$ chose soap water. Only $4 \%$ of the respondents would apply water for $20 \mathrm{~min}$. About $70 \%$ would only run the water for $1-10 \mathrm{~min}, 18 \%$ for $10-15$ $\mathrm{min}$, and $1 \%$ would run water for $30 \mathrm{~min}$.

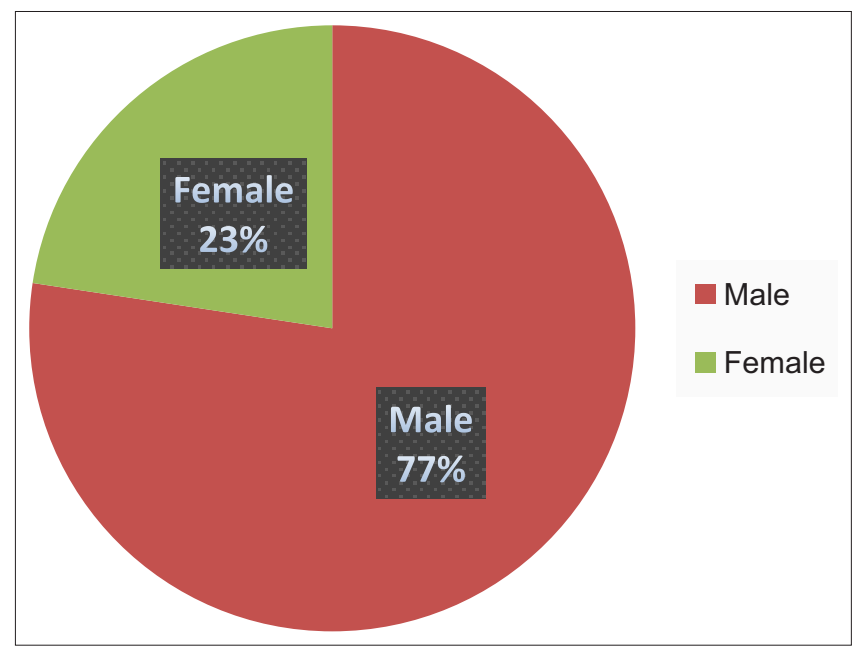

Figure 2: Distribution of burn patients by gender

A common misperception found in $82 \%$ of respondents of this study was that all burn wounds will eventually heal by itself. This can lead to delay in seeking treatment from medical professionals which can lead to further complications including infection and wound contamination. In moderate burn wounds, the relationship between admission-delay and the risk

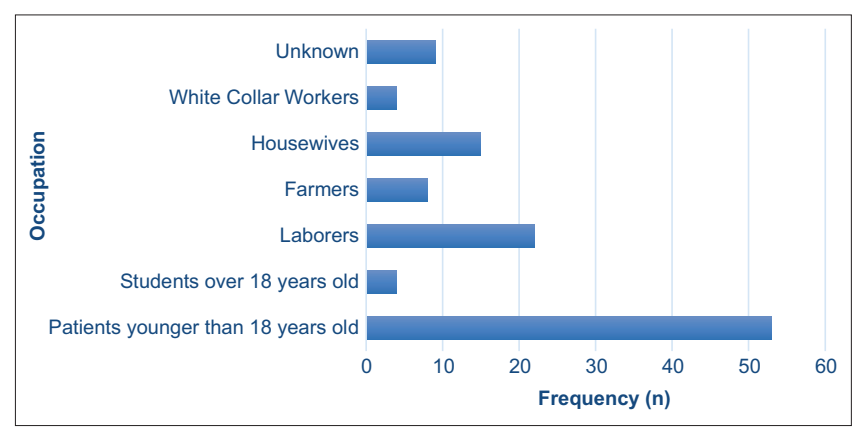

Figure 3: Occupation profile of burn patients 
of wound contamination and infection was studied and it was found that approximately $78 \mathrm{~h}$ was found to be the critical time limit that caused an increase in the rate of wound contamination and infection [34], [35], [36]. Other studies done in Saudi Arabia and Nepal also found that most, but not all the patients would seek medical assistance [1], [30].

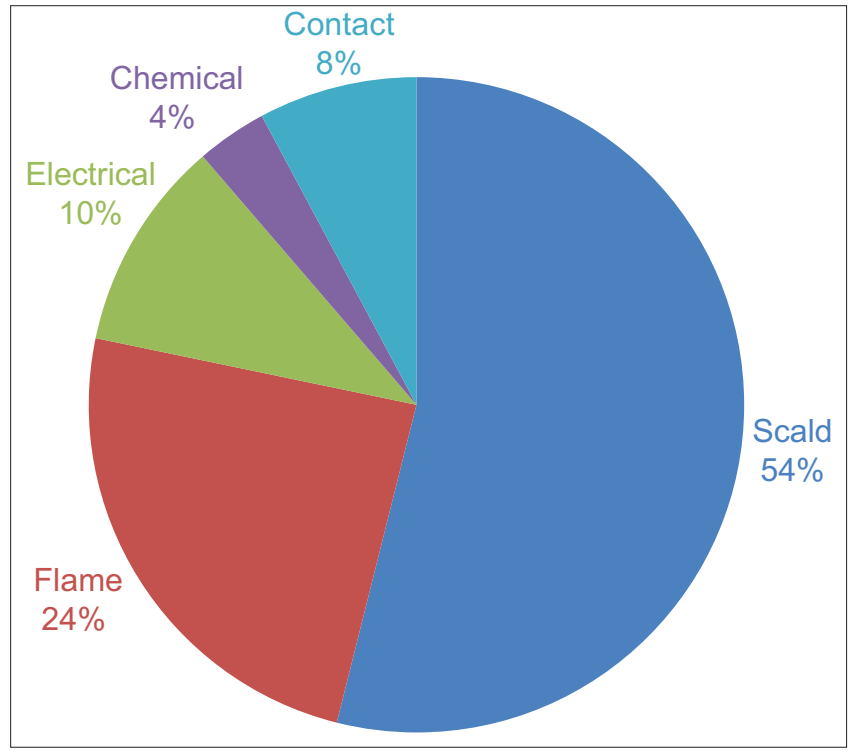

Figure 4: Etiology of burn injuries

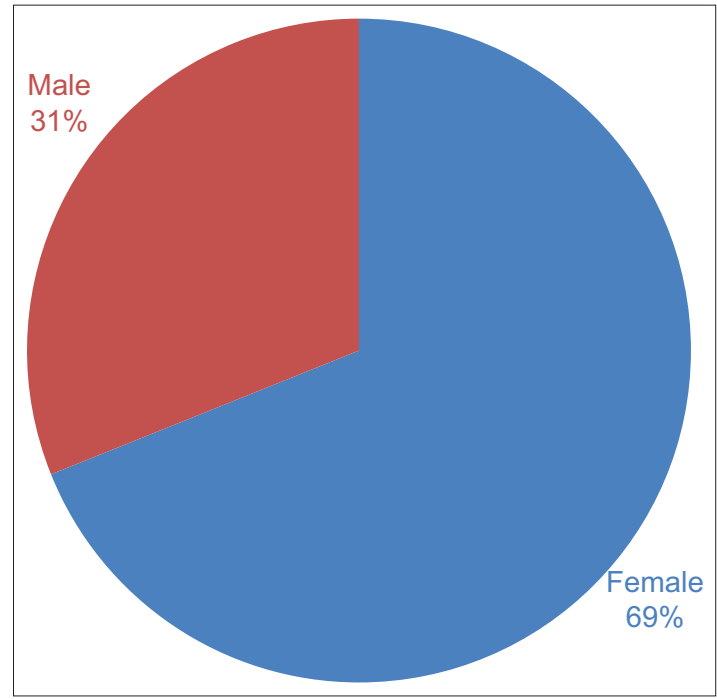

Figure 6: Gender distribution of survey respondents

Across the world, there are many different home remedies that are applied to burn wounds. In this study, honey $(77 \%)$, toothpaste (62\%), eggs $(58 \%)$, and hot oils $(38 \%)$ are some of the home remedies that respondents believed to improve burn wounds. Although some studies do show that honey can improve certain burn wounds [35], it is still best to avoid any application of home remedies. All of these traditional medicines tend to cause further damage to the top layers of the skin and leave the lower layers to be more susceptible

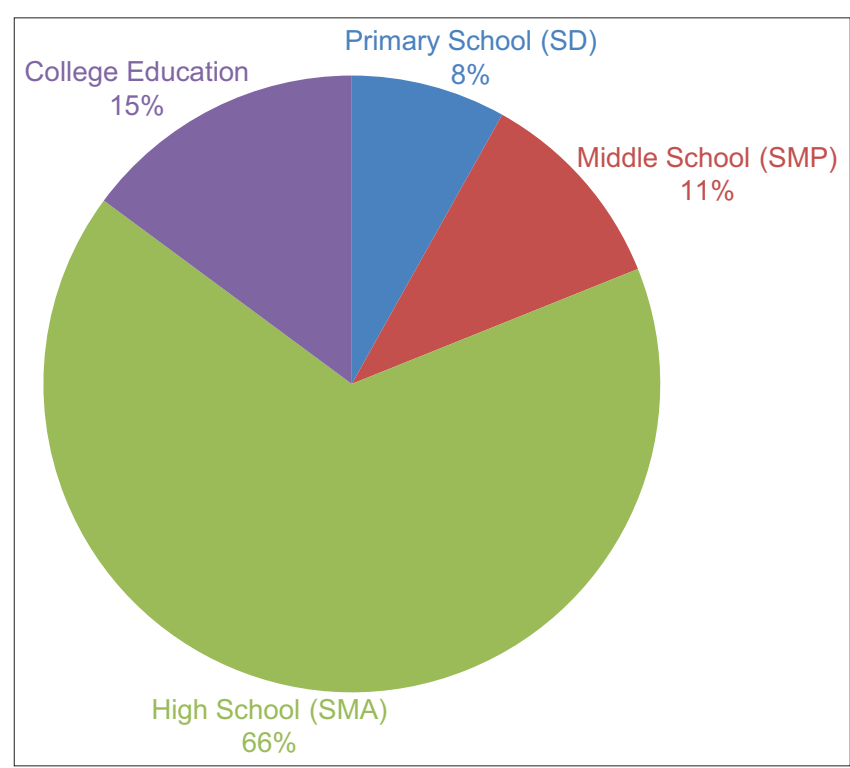

Figure 7: Education level of survey respondents

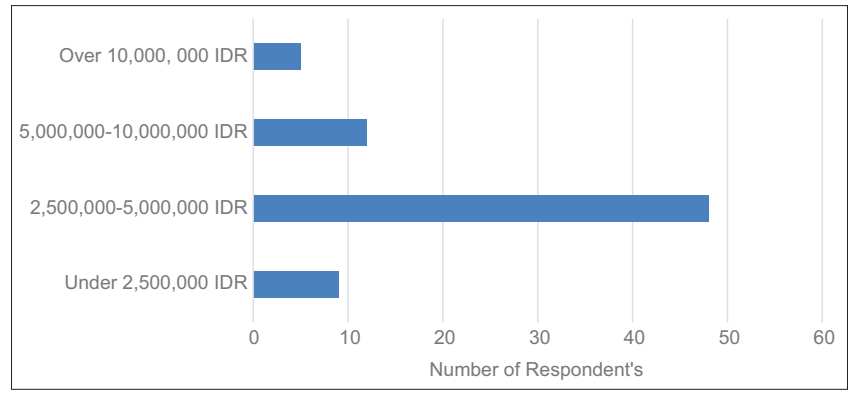

Figure 8: Monthly income of survey respondents

toward infection [30]. Majority of the respondents believed that application of ice can help burn wounds $(96 \%)$. Ice or iced water should not be used because intense vasoconstriction can lead to further burn progression. Cooling large areas of skin can also lead to hypothermia, especially in children [27], [33].

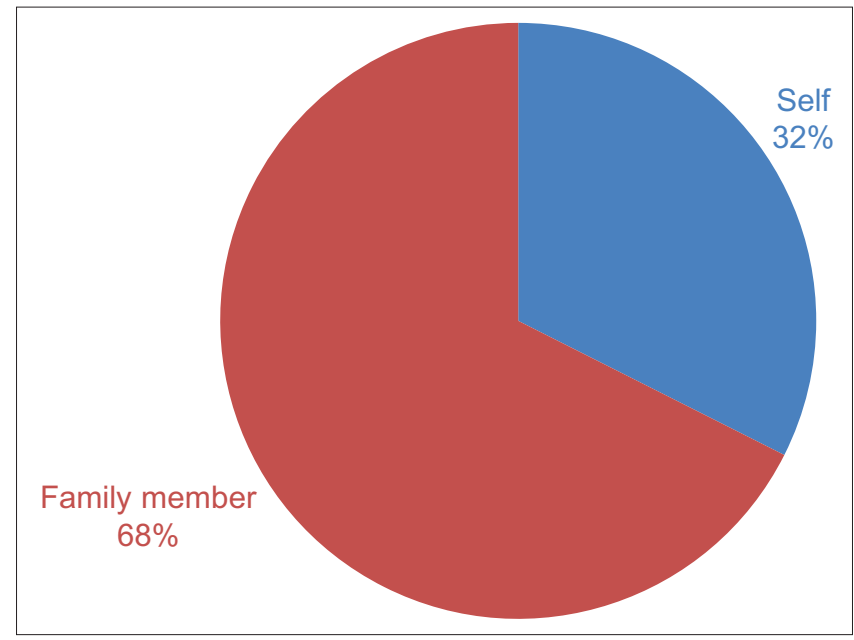

Figure 9: History of burn injuries in survey respondents

There are still huge disparities between urban and rural regions of Indonesia in healthcare. Further distances to health facilities and opportunity costs are just some of the factors that cause delays to health care 
facilities or not seeking treatment in rural areas around the world [34]. Due to this, it is extremely important to utilize community health workers

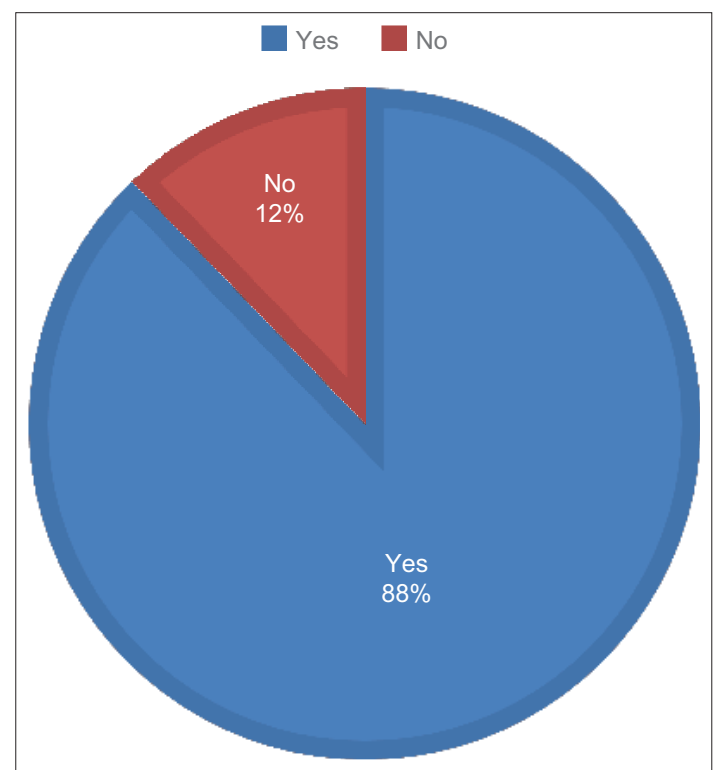

Figure 10: Respondents with children under 18 in the same household

to provide basic health knowledge about the first aid of burn wounds. Our study only shows a small glimpse into the alarming lack of burn first aid knowledge in the rural regions of Indonesia. There is also an urgent need for the Indonesian government to have better safety regulation when it comes to kitchen layout and safety as well as better waste management to prevent the practice of burning household wastes. Another challenge the government must tackle is better implementation of occupational health and safety rules. Poor and unsafe work conditions can both be considered as a cause and a consequence of poverty. Often times there are no consequences for the employers for not adhering to these rules. The informal nature of these jobs makes it more difficult for them to take responsibility.

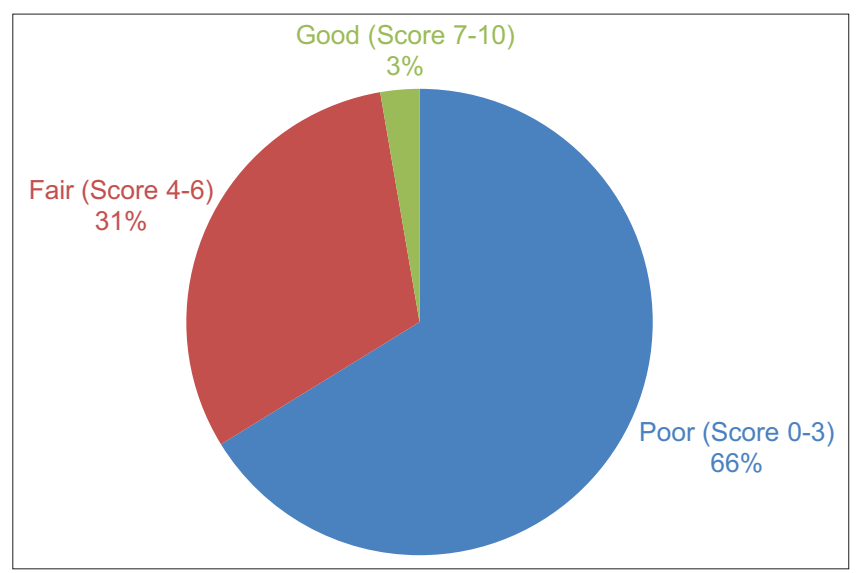

Figure 11: Burn first aid knowledge

Based on the results, this study showed that there was no significant correlation between education level of the respondents and their knowledge of first aid of burns. We categorized the respondent's into three groups based on their results: Poor, fair, and good. Most participants on other studies about first aid knowledge of burns are university graduates [10]. The absence of correlation between education level and first aid knowledge on burns shows that we as health care providers should work to educate all levels of the population. In rural areas, this might be more challenging because of lower education levels and awareness.

\section{Limitations}

This study was limited by not including patients that died and also patients that were referred to tertiary health care services. Incomplete medical records that would give crucial details such as what were the first aid treatments given to the patient before they arrived at the hospital, location of burn, socioeconomic backgrounds, and other factors that could possibly worsen the patient's condition.

The survey that we carried out also should have been conducted with a larger population to have a clearer understanding on the respondent's knowledge on first aid of burn injuries.

\section{Conclusions}

We discovered that children and housewives had a higher risk for scald injuries and laborers were at a higher risk for electrical and chemical burns. A majority of people in the rural area of Kulon Progo still have poor knowledge on the first aid of burns. There was no correlation between education levels and knowledge of first aid burns.

\section{References}

1. Stokes MA, Johnson WD. Burns in the third world: An unmet need. Ann Burns Fire Disasters. 2017;30(4):243-6.

PMid:29983673

2. Mehta K, Gyedu A, Otupiri E, Donkor P, Mock C, Stewart B. Incidence of childhood burn injuries and modifiable household risk factors in rural Ghana: A cluster-randomized, populationbased, household survey. Burns. 2020;2020:30522-2. https:// doi.org/10.1016/j.burns.2020.09.001

PMid:33077331

3. Ministry of Health and National Institute of Health Research and Development, 2018. National Report on Basic Health Research, Riskesdas; 2018.

4. E-Government: Open Data. Official Government of Kulon Progo; 2020. Available from: https://www.satudata.kulonprogokab. go.id/index.php/lihat/dda. [Last accessed on 2020 Nov 1]

5. Health Facilities. E-Government: Open Data. Official Government of Kulon Progo; 2020. Available from: https://www. satudata. kulonprogokab.go.id/index.php/lihat/dda_detil/16/ dataprasarana-pelayanan-kesehatan. [Last accessed on 2020 Nov 1].

6. Gyedu A, Stewart B, Mock C, Otupiri, E, Nakua, E, Donkor P, et al. Prevalence of preventable household risk factors for childhood 
burn injury in semi-urban Ghana: A population-based survey. Burns. 2016;42(3):633-8. https://doi.org/10.1016/j.burns.2015.11.004 PMid:26691868

7. Thoday K, Benjamin P, Gan M, Puzzolo E. The Mega conversion program from kerosene to LPG in Indonesia: Lessons learned and recommendations for future clean cooking energy expansion. Energy Sustain Dev. 2018;46:71-81. https://doi. org/10.1016/j.esd.2018.05.011

PMid:30333687

8. Biswas A, Abdullah AS, Dalal K, Deave T, Rahman F, Mashreky SR. Exploring perceptions of common practices immediately following burn injuries in rural communities of Bangladesh. BMC Health Serv Res. 2018;18:467. https://doi. org/10.1186/s12913-018-3287-3

9. Animesh B, Abu-Sayeed A, Toity D, Dalal K, Saidur M. Exploration of gaps and challenges in managing burn injury at district and sub-district government health care facilities in Bangladesh. Burns Open. 2019;4:16-21. https://doi. org/10.1016/j.burnso.2019.11.002

10. Kattan AE, AIShomer F, Alhujayri AK, Addar A, Aljerian A. Current knowledge of burn injury first aid practices and applied traditional remedies: A nationwide survey. Burns Trauma. 2016;4:37. https://doi.org/10.1186/s41038-016-0063-7 PMid:27826592

11. Wardhana A, Basuki A, Prameswara AD, Rizkita DN, Andarie AA, Canintika AF. The epidemiology of burns in Indonesia's national referral burn center from 2013 to 2015. Burns Open. 2017;1:2. https://doi.org/10.1016/j.burnso.2017.08.002

12. Hidayat TS, Noer MS, Saputro ID. Five years retrospective study of burns in $\mathrm{Dr}$ Soetomo general hospital Surabaya. Folia Med Indones. 2014;50:2.

13. Bramardipa AA, Sukrama ID, Budayanti NN. Bacterial pattern and its susceptibility toward antibiotic on burn infection in Burn Unit Sanglah general hospital. Bali Med J. 2019;8:1. https://doi. org/10.15562/bmj.v8i1.1456

14. Kawalec AM. Problems of Burns in Children: Opportunities for Health Improvement. London: InTech Open; 2018.

15. Hon HH, Kousari YM, Papadimos TJ, Tsavoussis A, Jeanmonod R, Stawicki SP. What"s new in critical illness and injury science? Nonaccidental burn injuries, child abuse awareness and prevention, and the critical need for dedicated pediatric emergency specialists: Answering the global call for social justice for our youngest citizens. Int J Crit IIIn Inj Sci. 2015;5(4):223-6. https://doi.org/10.4103/2229-5151.170854 PMid:26807388

16. Smith GS, Wellman HM, Sorock GS, Warner M, Courtney TK, Pransky GS, et al. Injuries at work in the US adult population: Contributions to the total injury burden. Am J Public Health. 2005;95(7):1213-9. https://doi.org/10.2105/ajph.2004.049338 PMid: 15983273

17. International Labour Organization. Subregional Office for SouthEast Asia and the Pacific. Occupational Safety and Health in Indonesia. International Labour Organization; 2004.

18. Song C, Chua A. Epidemiology of burn injuries in Singapore from 1997 to 2003. Burns. 2005;31(Suppl 1):S18-26. https://doi. org/10.1016/j.burns.2004.10.005 PMid:15649612

19. Bayat A, Ramaiah R, Bhananker SM. Analgesia and sedation for children undergoing burn wound care. Expert Rev Neurother. 2010;10(11):1747-59. https://doi.org/10.1586/ern.10.158 PMid:20977331

20. Krishnamoorthy V, Ramaiah R, Bhananker SM. Pediatric burn injuries. Int J Crit IIIn Inj Sci. 2012;2(3):128-34. https://doi. org/10.4103/2229-5151.100889

PMid:23181206
21. Gupta AK, Uppal S, Garg R, Gupta A, Pal R. A clinicoepidemiologic study of 892 patients with burn injuries at a tertiary care hospital in Punjab, India. J Emerg Trauma Shock. 2011;4(1):7-11. https://doi.org/10.4103/0974-2700.76820 PMid:21633560

22. PeckM, BrewerAC, Pressman M, BlankE, MickalideA. Hottapwater legislation in the United States. J Burn Care Res. 2010;31(6):91825. https://doi.org/10.1097/bcr.0b013e3181f93723 PMid:20864897

23. Poulos R, Hayen A, Finch C, Zwi A. Area socioeconomic status and childhood injury morbidity in New South Wales, Australia. Inj Prevent. 2007;13(5):322-7. https://doi.org/10.1136/ip.2007.015693 PMid:17916889

24. Peden M, Oyegbite K, Ozanne-Smith J, editors. World Report on Child Injury Prevention. Geneva: World Health Organization; 2008.

25. Johnson LS, Shupp JW, Pavlovich AR, Pezzullo JC, Jeng JC, Jordan $\mathrm{MH}$. Hospital length of stay-does 1\% TBSA really equal 1 day? J Burn Care Res. 2011;32(1):13-9. https://doi.org/10.1097/ bcr.0b013e318204b3ab

PMid:21131842

26. Louise CN, David M, John SK. Is the target of 1 day length of stay per $1 \%$ total body surface area burned actually being achieved? A review of paediatric thermal injuries in South East Scotland. Int J Burns Trauma. 2014;4(1):25-30. PMid:24624311

27. Hudspith J, Rayatt S. First aid and treatment of minor burns. BMJ. 2004;328(7454):1487-9. https://doi.org/10.1136/bmj.328.7454.1487 PMid: 15205294

28. Adapted from UNESCO Institute for Statistics, Sustainable Development Goals: Indonesia; 2020. Available from: http:// www. uis.unesco.org/en/country/id. [Last accessed on 2020 Nov 3]

29. Singer AJ, Gulla J, Thode HC Jr., Cronin KA. Pediatric first aid knowledge among parents. Pediatric Emergency Care. 2004;20(12):808-11. https://doi.org/10.1097/01. pec. $0000148028.53598 .5 \mathrm{c}$ PMid:15572967

30. Shrestha S, Gurung P. Awareness on prevention and first aid management of burn injury among adolesents. J Coll Med Sci Nepal. 2018;14:21330. https://doi.org/10.3126/jcmsn.v14i4.21330

31. Harvey LA, Barr ML, Poulos RG, Finch CF, Sherker S, Harvey JG. A population-based survey of knowledge of first aid for burns in New South Wales. Med J Aust. 2011;195(8):465-8. https://doi.org/10.5694/mja11.10836 PMid:22004398

32. Zimmerman TJ, Krizek TJ. Thermally induced dermal injury: A review of pathophysiologic events and therapeutic intervention. J Burn Care Res 1984;5(3):193-201. https://doi. org/10.1097/00004630-198405000-00002

33. Cuttle L, Pearn J, McMillan JR, Kimble RM. A review of first aid treatments for burn injuries. Burns. 2009;35(6):768-75. https:// doi.org/10.1016/j.burns.2008.10.011 PMid: 19269746

34. Serhat $O$, Güzin $O$, Abdullah E, Selçuk A, Ramazan K, Yasemin $\mathrm{H}$, et al. The effect of delayed admission in burn centers on wound contamination and infection rates. Ulus Travma Acil Cerrahi Derg. 2005;11(3):230-7.

PMid:16100669

35. Zbuchea A. Up-to-date use of honey for burns treatment. Ann Burns Fire Disasters. 2014;27(1):22-30.

PMid:25249844

36. Laksono AD, Wulandari RD, Soedirham O. Urban and rural disparities in hospital utilization among Indonesian adults. Iran J Public Health. 2019;48(2):247-55. https://doi.org/10.18502/ijph.v48i2.819

PMid:31205878 